Prepared for the U.S. Department of Defense, Defense Threat Reduction Agency under Contract IACRO\#B0946061 and the U.S. Department of Homeland Security and supported by the Northwest Regional Technology Center for Homeland Security

\title{
List of Contractors to Support Anthrax Remediation
}

KS Judd

AM Lesperance

May 14,2010

Pacific Northwest

NATIONAL LABORATORY

Proudly Operated by Battelle Since 1965 


\title{
DISCLAIMER
}

This report was prepared as an account of work sponsored by an agency of the United States Government. Neither the United States Government nor any agency thereof, nor Battelle Memorial Institute, nor any of their employees, makes any warranty, express or implied, or assumes any legal liability or responsibility for the accuracy, completeness, or usefulness of any information, apparatus, product, or process disclosed, or represents that its use would not infringe privately owned rights. Reference herein to any specific commercial product, process, or service by trade name, trademark, manufacturer, or otherwise does not necessarily constitute or imply its endorsement, recommendation, or favoring by the United States Government or any agency thereof, or Battelle Memorial Institute. The views and opinions of authors expressed herein do not necessarily state or reflect those of the United States Government or any agency thereof.

\author{
PACIFIC NORTHWEST NATIONAL LABORATORY \\ operated by \\ BATTELLE \\ for the \\ UNITED STATES DEPARTMENT OF ENERGY \\ under Contract DE-AC05-76RL01830 \\ Printed in the United States of America \\ Available to DOE and DOE contractors from the \\ Office of Scientific and Technical Information, \\ P.O. Box 62, Oak Ridge, TN 37831-0062; \\ ph: (865) 576-8401 \\ fax: (865) 576-5728 \\ email: reports@adonis.osti.gov
}

\author{
Available to the public from the National Technical Information Service, \\ U.S. Department of Commerce, 5285 Port Royal Rd., Springfield, VA 22161 \\ ph: (800) 553-6847 \\ fax: (703) 605-6900 \\ email: orders@ ntis.fedworld.gov \\ online ordering: http://www.ntis.gov/ordering.htm
}




\section{List of Contractors to Support Anthrax Remediation}

During August 2008, the Pacific Northwest National Laboratory (PNNL) led a series of workshops with businesses, building owners, and critical service providers in the Seattle urban area to identify their priority needs to support restoration and recovery efforts after a wide-area anthrax release. One of the priority needs identified by private sector businesses and building owners was a list of "credible cleanup contractors" who could provide anthrax remediation support. Because of the uncertainty around how remediation activities would be prioritized and how long it might take, participants sought ways to take control over cleanup of their own assets. Participants wanted to understand who might be qualified to support anthrax remediation and how to go about engaging such contractors.

The U.S. Environmental Protection Agency (EPA) is the lead agency responsible for sampling, analysis, monitoring, removal or cleanup of anthrax contaminated buildings, residences and open areas. To support such environmental cleanup efforts, EPA maintains a list qualified response contractors that are available throughout the nation. Other response contractors may also be well qualified to clean up private property, but there is currently no comprehensive list of EPA and other contractors qualified to support anthrax remediation. A list of contractors that supported EPA and other responders with remediation of the anthrax attacks on Capitol Hill, including a description of their contribution to cleanup, is presented in Table 1 below.

While private businesses may want to engage in dialogue with potential contractors, in the case of a wide-area anthrax incident there may be a significant gap in the number of qualified contractors available. It is possible, however, that contractors would be able to add capacity in the event of a wide-area release in order to support both EPA and private entities.

The EPA recommends that businesses interested in hiring a qualified clean-up firm to assist with anthrax remediation on their property ensure that clean-up contractors meet the following requirements:

- Bonded and insured,

- Meet local and state licensing and certification,

- Be able to provide proof of training for those employees who will be working on the job,

- Meet OSHA requirements for hazardous waste operations and emergency response training as outlined 20 Code of Federal Regulations (CFR) 1910.120,

- Show that they have a medical surveillance program as outlined 20 CFR 1910.120 (b),

- Show that they have a respirator protection program as outlined in 20 CFR 1910.134,

- Provide proof of biological/chemical agent training,

- Be familiar with decontamination procedures,

- Be trained to use the specific decontamination technologies to be applied, and

- Use NIOSH certified CBRNE respiratory equipment. 
Table 1. Capitol Hill Anthrax Incident Contractors and Tasks/Roles in Cleanup ${ }^{1}$

\begin{tabular}{|c|c|c|}
\hline Organization & Expertise & Task/Role Performed in Capitol Hill Cleanup \\
\hline $\begin{array}{l}\text { Shaw Group } \\
\text { (formerly IT } \\
\text { Corporation) }\end{array}$ & Removal & $\begin{array}{l}\text { Prepared buildings for decontamination. Conducted and supported } \\
\text { decontamination operations, including fumigation with chlorine dioxide } \\
\text { gas. Decontaminated interior surfaces of buildings, other structures, cars, } \\
\text { and other vessels. Provided for collection, containment, and transportation } \\
\text { and disposal of contaminated materials from the site operations. } \\
\text { Provided support to EPA sampling teams and other federal responders, } \\
\text { including response technicians, to assist with decontamination activities. }\end{array}$ \\
\hline Tetra Tech EM, Inc. & Technical & $\begin{array}{l}\text { Provided the on-scene coordinator and incident commander fumigation } \\
\text { design procedures, including details on fumigant delivery; concentration; } \\
\text { operating conditions, such as temperature and humidity; fumigant } \\
\text { containment and recovery; and monitoring of parameters. Provided } \\
\text { detailed design for delivery of fumigant, equipment requirements and } \\
\text { specifications, flow schematics, and detailed schedules and operating } \\
\text { procedures to use during fumigation. Provided a chlorine dioxide specialist } \\
\text { to assist EPA in overseeing the fumigation setup. } \\
\text { Provided technical support to the on-scene coordinator in developing } \\
\text { chronology of events at the site, including researching various files, } \\
\text { documents, and logbooks in order to develop a comprehensive report. } \\
\text { Monitored and assisted with the oversight of the chlorine dioxide } \\
\text { fumigation process. Assisted with health and safety matters at the site, } \\
\text { conducted sampling, assisted and oversaw off-gassing, inventory, and } \\
\text { return items being treated. } \\
\text { Supported the on-scene coordinator in conducting presentations and } \\
\text { briefings related to post-treatment and design of chlorine dioxide use in the } \\
\text { heating, ventilation, and air-conditioning system. } \\
\text { Sampled a small number of critical items (plastic, leather, and polyester) for } \\
\text { ethylene oxide and its derivations to determine how the ethylene oxide and } \\
\text { its derivatives are maintained in the materials and off-gas over time. }\end{array}$ \\
\hline Earth Tech, Inc. & Removal & $\begin{array}{l}\text { Provided decontamination services and other direct support to sampling } \\
\text { teams. Decontaminated interior surfaces of buildings, other structures, and } \\
\text { interior and exterior surfaces of cars and other vessels identified by the on- }\end{array}$ \\
\hline
\end{tabular}

${ }^{1}$ GAO. Capitol Hill Anthrax Incident: EPA's cleanup was successful; opportunities exist to enhance contractor oversight. GAO-03-686. Washington, DC: June 2003. Available at: http://www.gao.gov/new.items/d03686.pdf.

${ }^{2}$ IT Corporation declared bankruptcy in 2002, but substantially all of the company's assets and businesses, including the remediation business, were purchased by Shaw Group, 


\begin{tabular}{|c|c|c|}
\hline & & $\begin{array}{l}\text { scene coordinator. Collected all expended cleaning agents and materials for } \\
\text { treatment and/or disposal. } \\
\text { Provided decontamination facilities and services for response personnel } \\
\text { and their equipment. Inventoried items - segregating clean and } \\
\text { contaminated materials and salvageable and expendable items-and } \\
\text { provided documentation of inventoried items. } \\
\text { Proposed a decontamination strategy for critical items (including personal } \\
\text { items such as photographs, framed diplomas, and equipment). } \\
\text { Decontaminated critical and salvageable items from the Capitol Complex, } \\
\text { including setting up work zones for items to be decontaminated and for } \\
\text { personnel decontamination. } \\
\text { Returned property after decontamination. } \\
\text { Provided contamination reduction and isolation facilities and operations } \\
\text { that improve and ensure safe access to contaminated areas and items and } \\
\text { prevent further spread of contamination. }\end{array}$ \\
\hline $\begin{array}{l}\text { Environmental } \\
\text { Quality } \\
\text { Management, Inc. }\end{array}$ & Removal & $\begin{array}{l}\text { Provided personnel and equipment, including portable decontamination } \\
\text { facility. Collected expended cleaning agents and materials for treatment } \\
\text { and/or disposal. Disposed of materials or items that could not be } \\
\text { decontaminated. }\end{array}$ \\
\hline $\begin{array}{l}\frac{\text { CDM Federal }}{\text { Programs }} \\
\text { Corporation }\end{array}$ & Support & $\begin{array}{l}\text { Oversaw preparation, handling, placement, and collection of spore strips } \\
\text { used during fumigation with chlorine dioxide gas and ethylene oxide gas. } \\
\text { Developed a procedure for spore strip emplacement; removal; and critical } \\
\text { item tagging, tracking, and shipping. } \\
\text { Provided sampling such as swipe and high efficiency particulate air (HEPA) } \\
\text { vacuum (including efforts to collect, prepare, and ship samples), item } \\
\text { decontamination, and minor remediation work. } \\
\text { Supported critical item degassing activities in Beltsville, Maryland. } \\
\text { Maintained critical item inventories and coordinated the release and return } \\
\text { of critical items to congressional staffers. } \\
\text { Supported chlorine dioxide decontamination of congressional mail } \\
\text { packages. }\end{array}$ \\
\hline Weston Solutions & Technical & $\begin{array}{l}\text { Developed various documents/plans to be used during the response } \\
\text { activities (e.g., standard operating procedures for sampling, } \\
\text { decontamination, source } \\
\text { reduction). Provided reconnaissance, photo documentation, and sampling } \\
\text { of congressional office buildings. } \\
\text { Provided technical support for the selection and implementation of } \\
\text { decontamination procedures; building-specific plan development for } \\
\text { anthrax remediation, including sampling plans, isolation plans, } \\
\text { decontamination plans, and item recovery plans; and sampling support for } \\
\text { anthrax analysis using HEPA and wipe sampling techniques; perform }\end{array}$ \\
\hline
\end{tabular}




\begin{tabular}{|c|c|c|}
\hline & & $\begin{array}{l}\text { oversight of removal crews. Provided swab and HEPA sampling and } \\
\text { decontamination support. } \\
\text { Provided bag-and-tag operations of critical and salvageable items in } \\
\text { congressional office buildings. Provided air monitoring operations during } \\
\text { chlorine dioxide fumigation operations. }\end{array}$ \\
\hline $\begin{array}{l}\text { Ecology \& } \\
\text { Environment, Inc. }\end{array}$ & Technical & $\begin{array}{l}\text { Developed sampling and decontamination plans, sample labels and chain-of } \\
\text { custodies, and maps to support sampling activities and to track sampling } \\
\text { results. } \\
\text { Performed sampling, monitoring, and decontamination of areas in the } \\
\text { Capitol Hill complex. Conducted sampling tracking and handling activities, } \\
\text { including preparing samples for shipping. } \\
\text { Compiled and reviewed background data and organize site documentation } \\
\text { files. } \\
\text { Provided technical support to the operations section and support to the } \\
\text { EPA Mobile Lab. }\end{array}$ \\
\hline$\underline{\text { Lockheed Martin }}$ & Support & $\begin{array}{l}\text { Assisted in monitoring temperature and relative humidity inside office } \\
\text { buildings and in monitoring chlorine dioxide, chlorine, wind speed and } \\
\text { direction, temperature and relative humidity in surrounding area. } \\
\text { Assisted with development and evaluation of anthrax fumigation } \\
\text { procedures using spore strips in a test facility and train other contractors in } \\
\text { the handling and placement of spore strips in the office building. } \\
\text { Provided ambient air monitoring for chlorine dioxide using tape meters and } \\
\text { a portable meteorological tower to document that no chlorine dioxide is } \\
\text { being emitted from the treatment area. Provided on-site assistance to } \\
\text { ensure that spore strip sampling is being conducted properly and that data } \\
\text { management is being performed accurately and completely. }\end{array}$ \\
\hline $\begin{array}{l}\text { Guardian } \\
\text { Environmental } \\
\underline{\text { Services }}\end{array}$ & Removal & $\begin{array}{l}\text { Assisted in the removal of items from the contaminated office suites in the } \\
\text { congressional office buildings, including removal of contaminated office } \\
\text { furniture, office equipment, and carpet. Constructed isolation chambers, } \\
\text { decontamination chambers, and other related structures. }\end{array}$ \\
\hline$\underline{\text { URS }}$ & Technical & Provided sampling for anthrax in the Capitol Hill complex. \\
\hline$\underline{\mathrm{TSI} I \mathrm{InC}}$ & Supplies & Provided Porta Count plus respirator fit tester. \\
\hline $\begin{array}{l}\frac{\text { Kemron }}{\text { Environmental }} \\
\underline{\text { Services, Inc. }}\end{array}$ & Removal & $\begin{array}{l}\text { Performed air sampling and perform HEPA vacuuming services. } \\
\text { Removed critical items and documents, spray affected areas with chlorine } \\
\text { dioxide, and perform cleaning and breakdown of work zones. } \\
\text { Assisted EPA in the evaluation of possible remediation of the heating, } \\
\text { ventilation, and air-conditioning system, including evaluation of affected } \\
\text { areas, and construction of critical barriers inside the ductwork to isolate } \\
\text { affected areas from uncontaminated areas. After fumigation of the affected }\end{array}$ \\
\hline
\end{tabular}




\begin{tabular}{|c|c|c|}
\hline & & $\begin{array}{l}\text { heating, ventilation, and air conditioning system, provided confirmatory } \\
\text { sampling support, interior duct sampling, additional cleaning of the system } \\
\text { (including post-fumigation scrub down inside the ducts), and removal of } \\
\text { duct insulation. }\end{array}$ \\
\hline $\begin{array}{l}\text { HMHTTC Response } \\
\text { Team, Inc. }\end{array}$ & Removal & $\begin{array}{l}\text { Performed cleanup activities, including construction and removal of } \\
\text { isolation barriers, HEPA vacuuming operations, and application of liquid } \\
\text { chlorine dioxide. } \\
\text { Provided 24-hour support for decontamination and rescue operations at } \\
\text { the Capitol Hill anthrax site. }\end{array}$ \\
\hline $\begin{array}{l}\text { Southwest } \\
\text { Research Institute } \\
\end{array}$ & Laboratory & $\begin{array}{l}\text { Provided analysis of spore strips placed in various locations during cleanup } \\
\text { operations. Received and performed daily observations of thousands of } \\
\text { spore strips. }\end{array}$ \\
\hline $\begin{array}{l}\frac{\text { University of }}{\text { California- }} \\
\text { Berkeley } \\
\text { Sponsored Projects } \\
\text { Office }\end{array}$ & Technical & $\begin{array}{l}\text { Participated in and supported program plan development relating to spore } \\
\text { sterilization technologies for remediation of federal facilities. } \\
\text { Developed experimental and field test plans and methodologies for } \\
\text { characterization/modeling spore killing processes and kinetics and factors } \\
\text { that affect the efficacy of spore killing in field-scale applications. } \\
\text { Established laboratory systems for the measurement of gas phase sporicidal } \\
\text { effects at federal office and mail facilities. Provided laboratory analytical } \\
\text { support for measurement of gas phase sporicidal effects. } \\
\text { Developed experimental and test plans and methodologies for assessing } \\
\text { and validating spore killing processes. } \\
\text { Determined the concentrations of chlorine dioxide needed to } \\
\text { decontaminate anthrax on Capitol Hill. Prepared } 31,500 \text { test strips } \\
\text { containing a bacillus similar to anthrax and send to Capitol Hill. The exposed } \\
\text { strips were be sent to labs and results then were be sent to the University } \\
\text { of California, Berkeley, for the consolidated final report. }\end{array}$ \\
\hline $\begin{array}{l}\text { Silva Consulting } \\
\text { Services, LLC }\end{array}$ & Technical & $\begin{array}{l}\text { Maintained sample management system software in a private, secure } \\
\text { environment on the Internet. Provided EPA personnel and designated } \\
\text { contractor personnel secure, controlled access to the database. This system } \\
\text { was able to generate a large variety of reports to address particular } \\
\text { questions about sampling results. }\end{array}$ \\
\hline $\begin{array}{l}\frac{\text { Science }}{\text { Applications }} \\
\text { International } \\
\text { Corporation }\end{array}$ & Technical & $\begin{array}{l}\text { Provided consulting services to EPA on-scene coordinator in environmental } \\
\text { remediation of anthrax-contaminated buildings in the Capitol Hill complex. } \\
\text { Support included data interpretation of the spore strips used to test the } \\
\text { efficacy of the kill of anthrax, data validation, review of documents, } \\
\text { assistance in document preparation, and report writing. Coordinated efforts } \\
\text { with the University of California, Berkeley. }\end{array}$ \\
\hline
\end{tabular}




\begin{tabular}{|c|c|c|}
\hline Biomarine, $\operatorname{lnc}{ }^{3}$. & Supplies & $\begin{array}{l}\text { Provided equipment that included biopaks, facemasks, oxygen cylinders, gel } \\
\text { tubes, foam scrubbers, coolant canister foam, flow restrictors, and biopak } \\
\text { service and retrofit kits. }\end{array}$ \\
\hline $\begin{array}{l}\text { Envirofoam } \\
\text { Technologies, Inc. }\end{array}$ & Supplies & Provided Sandia decon foam and backpack dispensing units. \\
\hline Safeware, Inc. & Supplies & Provided respirators with battery and cartridge \\
\hline Airgas Safety & Supplies & Provided air purifying respirators. \\
\hline$\frac{\text { Sabre Oxidation }}{\text { Technologies, Inc. }}$ & Technical & $\begin{array}{l}\text { Provided engineering support during the assessment of the feasibility and } \\
\text { design of the systems for fumigating air handling return system. }\end{array}$ \\
\hline $\begin{array}{l}\text { U.S. Art Company, } \\
\text { Inc. }\end{array}$ & Technical & $\begin{array}{l}\text { Provided training on proper procedures for handling, packaging, and } \\
\text { decontaminating artifacts (paintings, sculptures, and other art forms) from } \\
\text { the Hart Senate Office Building. }\end{array}$ \\
\hline $\begin{array}{l}\text { Mine Safety } \\
\text { Appliances }\end{array}$ & Supplies & Provided self-contained breathing apparatus system. \\
\hline $\begin{array}{l}\text { New Horizons } \\
\text { Diagnostics } \\
\text { Corporation } \\
\end{array}$ & Supplies & Provided anthrax detection kits. \\
\hline $\begin{array}{l}\frac{\text { Coastal Safety \& }}{\text { Health Services, }} \\
\text { Inc. }\end{array}$ & Supplies & Provided indoor air quality meters. \\
\hline
\end{tabular}

Table 2 below includes additional remediation service providers and product vendors, beyond those that supported cleanup of the Capitol Hill anthrax events. It should be noted that any references to any specific commercial products, process, or service by trade name, trade mark, manufacturer, or otherwise, does not constitute or imply its endorsement, recommendation, or favoring by the authors of this report or the United States Government.

Table 2. Other remediation service providers and product vendors

\begin{tabular}{|l|l|}
\hline Organization & Expertise \\
\hline Sterilization Services & $\begin{array}{l}\text { Sterilization services and vendors for items to be decontaminated off-site. Has a variety of } \\
\text { ethylene oxide sterilizer sizes and can process quantities up to a fully loaded tractor-trailer } \\
\text { truck of items at and has a mobile sterilization unit capable of processing over } 1500 \text { cubic } \\
\text { feet of items. }\end{array}$ \\
\hline
\end{tabular}

\footnotetext{
${ }^{3}$ A division of Neutronics.
} 


\begin{tabular}{|c|c|}
\hline$\underline{\text { Steris Corporation }}$ & $\begin{array}{l}\text { Sterilization services and vendors for items to be decontaminated off-site. Provides several } \\
\text { sterilization services including Gamma Irradiation, 100\% Ethylene Oxide (EO), and Electron } \\
\text { Beam (E-beam) Technologies. } \\
\text { Liquid decontamination agents: Spor Klenz } \\
\text { Biological Indicators }\end{array}$ \\
\hline $\begin{array}{l}\text { Sabre Technical } \\
\text { Services, LLC }\end{array}$ & Chlorine dioxide Fumigation Services and vendors \\
\hline $\begin{array}{l}\text { ClorDiSys Solutions, } \\
\text { Inc. }\end{array}$ & Chlorine dioxide Fumigation Services and vendors \\
\hline $\begin{array}{l}\text { Strategic Technology } \\
\text { Enterprises, Inc. }\end{array}$ & Vaporous hydrogen peroxide services and vendors \\
\hline Bioquell (UK) & Vaporous hydrogen peroxide services and vendors \\
\hline $\begin{array}{l}\text { Guided Wave Process } \\
\text { Analytical Chemistry }\end{array}$ & Peroxide monitors \\
\hline $\begin{array}{l}\text { Grey Wolf Sensing } \\
\text { Solutions }\end{array}$ & Chlorine dioxide monitors - Direct Sense Tox multi-gas monitor \\
\hline Scott Health \& Safety & Chlorine dioxide monitors - Sentinel II area monitor \\
\hline $\begin{array}{l}\text { Clean Earth } \\
\text { Technologies, LLC }\end{array}$ & Liquid decontamination agents: Peridox ${ }^{\mathrm{TM}}$ \\
\hline $\begin{array}{l}\text { Department of } \\
\text { Health and Senior } \\
\text { Services }\end{array}$ & Analysis of environmental samples- LRN laboratory \\
\hline Stericycle Inc. & Medical Waste Incineration \\
\hline Apex Laboratories Inc & Biological Indicators \\
\hline
\end{tabular}

